\title{
Evolution of Physical Education in Institutions of Higher Learning and Its Impact on Curriculum
}

\author{
Tao Shangwu \\ College of Physical Education, Yan'an University, Yan'an, 716000, China \\ 236488990@qq.com
}

\begin{abstract}
Using the method of literature research to sort out the guiding ideology that affects the $P E$ teaching in Chinese colleges and universities, three kinds of thought theories, which have the greatest influence on the physical education curriculum in colleges and universities in our country, are the technical education thought, constitutional education thought and the "Health First" guiding ideology. Under the influence of kinds of theories, China has promulgated four college physical education programs over the years. The evolution of physical education ideas in colleges and universities has an important influence on the goals, teaching contents and ways of physical education curriculum.
\end{abstract}

Keywords-Colleges and universities; Sports thoughts; Evolution; Influence

\section{INTRODUCTION}

After the founding of the People's Republic of China, the national economy of our country underwent several profound changes with the restoration of the national economy and the overall period of socialist construction. Ten years of the cultural revolution led to the collapse of the national economy and the new reform and opening up since the Third Plenary Session of the 11th Central Government period. Social turmoil led to changes in thinking, affecting the development of physical education in colleges and universities in our country are mainly thoughts of technical education, physical education and "health first" three guiding ideology, under the influence of these three ideas, Enacted four college physical education program. The current sports thoughts and the status quo of physical education in colleges and universities have its own rationality and value. With the progress of the times and social development, the physical education curriculum in colleges and universities has been deepening and reforming and developing. Through combing the evolution of thoughts of physical education in colleges and universities in our country, it can provide new ideas for the reform of physical education in colleges and universities and promote the all-round development of personnel training in colleges and universities.

\section{The Evolution OF SCHOOL PE THOUGHTS AFTER THE FOUNDING OF NEW CHINA}

\section{A. Sports skills education ideas}

The educational thinking of sports skills originated from the study of Soviet school physical education theory by school physical education workers in our country after the founding of New China. After liberation, our country comprehensively studied the Soviet Union physical education teaching thought. Teaching focus on "three bases" and "three centers", that is, basic knowledge, skills and skills and teachers, teaching materials and classroom three centers. In the teaching of physical education focus on basic knowledge and sports technology teaching, at the same time pay attention to the acquisition and mastery of motor skills. However, in the actual teaching, it is emphasized that the importance of sports skills and skills, emphasis on the promotion of athletic ability, leading to a wide range of controversies, but the sports technology education does have a significant impact on our school physical education, and will This effect continues.

\section{B. Physical education thought}

The idea of physique education is put forward by our local scholars represented by Mr. Xu Yingchao. The term "physical education" was first proposed in 1978. After the scientific and systematic exploration of physical education in schools, the concept of constitutional education was established as: Sports is for all students, enhance students' physical education. The background put forward by constitutional education was that when the "Cultural Revolution" basically destroyed our education system and the school physical education was also in a state of stagnation, the physical quality of the nationals dropped drastically as a result of the turmoil of the past decade. We must improve and enhance the students' health. The constitution education thought is put forward in line with the current national conditions, to adapt to the needs of social development, and effectively promote the development of school physical education in our country. It plays an important role in school physical education. However, the curriculum guided by the ideology of physical education places too much emphasis on physical exercise and simplifies the teaching content and form of physical education, which poses certain problems. With the continuous improvement of society, the ideology of constitutional education should be continuously updated and improved, advancing with the times. 


\section{A variety of co-exist educational ideas}

Since the reform and opening up, China's school physical education has entered an era of all-round development and reform, a large number of foreign schools of sports ideas and practices into the country, the school physical education teaching show flourishing situation, which greatly promoted our school physical education development of. These ideas include happy sports, lifelong sports, successful sports, active sports and so on. Here we give a brief review of the development of these ideas. Happy sports advocate is from emotion, emotional learning interest and creativity, in autonomy and happiness in physical education schools and exercise. However, there is a great difference between the Japanese sports practice in our country and the Japanese curriculum in the beginning of Happy Sports. It is easy to become a "sheep-style" physical education lesson. The true connotation of the Happy Sports Thought has not been fully clarified yet. Biased. Lifelong physical education is put forward by French educator Lange Lang. The main point of view is that sport is an indispensable part of life. From the beginning to the end of life, all are engaged in physical exercise. The idea of lifelong sports makes people realize that sports should not be limited to life A certain stage, but throughout the whole life.

\section{D. "Health First" educational thought}

Since the founding of the People's Republic of China, the guiding ideology of "health first" has been clearly put forward twice. The first was January 15, 1951, in which Chairman Mao Zedong said in his written reply to the then Minister of Education, Ma Xulun, "put forward health first and study the second principle, I think it is correct." The second is the basic premise that "healthy body and soul are the service for adolescents to serve the motherland and the people" in the "Decision of the State Council on the CPC Central Committee and the State Council on Deepening Educational Reform and Promoting Quality-oriented Education" in June 1999. It is also a manifestation of the national vitality. The sports of schools Work should establish the guiding ideology of health first [1]. The guiding ideology of putting forward the health first twice is put forward against the background of the adolescent students' physical fitness decline and their poor health status. Its basic purpose is to vigorously enhance the physical quality of young people and enhance China's overall national strength [2].

\section{The EVOLUTION OF PHYSICAL EDUCATION SYLLABUS IN COLLEGES AND UNIVERSITIES AFTER THE FOUNDATION OF NEW CHINA}

Physical education syllabus is a guiding syllabus for sports disciplines, including the purpose of teaching, requirements, content and distribution of hours of teaching. Ordinary college physical education curriculum is the preparation of physical education teaching plan, writing physical education teaching materials, the implementation of physical education and evaluation of teaching effectiveness standards. Since the founding of new China, our country's education department has formulated and promulgated a total of 4 college physical education syllabus.

\section{A. "General Physical Education Pilot Teaching Syllabus"}

The Pilot Program of Physical Education Courses in General Colleges and Universities is the first university physical education program established by the education department of our country after the founding of People's Republic of China. The outline is based on the study and reference of the Outline of Physical Education Syllabus for Higher Education Institutions in the Soviet Union. In January 1956 promulgated by the Ministry of Higher Education enacted. In this outline, the purpose of physical education in colleges and universities is to make the students become senior construction personnel capable of defending the motherland and engaging in productive labor, and loyal to the motherland and the cause of socialism [3]. The task of higher education that can be educated is to cultivate talents with communist moral qualities. Based on the labor and health system, we can grasp the basic knowledge and skills of using sports to achieve the standard of secondary labor and health system. The content of the textbook is divided into practice and theory of two parts, about $94 \%$ of the practice part, of which gymnastics and track and field dominated, accounting for about $85 \%$. The content of the outline of the basic reference to the contents of the Soviet Union, the idea of technical education as a guide, in teaching emphasis on basic knowledge, basic skills and basic qualities, namely "three basic", the main "three centers" that teachers, Classroom and textbooks as the center.

\section{B. "The outline of teaching materials for general physical education in Colleges and universities"}

"Colleges and universities physical education teaching outline" is the Ministry of education in July 1961 second the Ministry of higher physical education teaching outline, the outline to determine the university physical education is to enhance the physical fitness of students, the students communist education, study hard, actively participate in labor, ready to defend the motherland. Teaching content is divided into the basic part and the selected part, the basic part of the total accounted for $65 \%$, still dominated by gymnastics and track and field, an increase of the national traditional sports martial arts, selected materials to increase the ball, swimming and other projects [4]. This syllabus for the first time proposed to enhance students' physique, the choice of teaching content is richer and more reasonable, and initially get rid of the impact of the Soviet Union physical education curriculum is 
our college physical education teaching independent construction card is, but because of the Cultural Revolution of 10 years, higher The physical education in schools is

\section{C. "General Physical Education Courses Syllabus"}

Decade of the Cultural Revolution, so that China's primary, secondary and primary schools of physical education by catastrophic impact on the physical health of students dropped significantly in the face of this situation, with the approval of the State Council, the Ministry of Education and the former State Sports Commission Organize the national school sports health work experience exchange meeting, this is our country school sports education has a profound influence Yangzhou meeting. The primary task of establishing school physical education at this meeting is to exercise and enhance physical fitness. The evaluation standard of physical education in school is whether the students' physical health is improved or not. In August 1979, the Ministry of Education of Yangzhou formulated and promulgated the third college physical education program in our country, which is the "General Physical Education Courses Syllabus for Higher Education Institutions" and was revised in April 1985. This syllabus will definitely enhance the students' physique as the objective of physical education in colleges and universities. At the same time, students who have failed to pass the physical education course for 140 hours and those who fail the physical education course can not be awarded degree or diploma. After the Cultural Revolution, the new outline re-established the order of physical education in colleges and universities. Both technical education thoughts and constitutional education thoughts were emphasized. The contents of the courses were more varied. Compared with the first two sections, there was a clear development and progress.

\section{D. "National College Physical Education Teaching Guidelines"}

"National Colleges and Universities Sports Curriculum Teaching Guidelines" is issued in August 1992 the Ministry of Education issued the fourth college physical education syllabus, This outline put forward for the first time that the essential function of physical education is to educate people. The task of teaching is to promote students 'comprehensive physical and mental development, pay attention to cultivating students' sports ideas and cultivating the habit of physical exercise, and integrate lifelong education after the thought of skill education and constitution education thought of. In August 2002, the Ministry of Education revised the teaching body (1992) No. 11 which has been implemented for 10 years and issued a new teaching art (2002) No. 13 document. The new outline summarizes the curriculum construction of physical education in colleges and universities and the teaching reform experience has more comprehensive and perfect development than all aspects of the old outline. The new outline makes it clear that the nature of physical education curriculum in colleges and universities is a public compulsory course to achieve health promotion and sports literacy improvement. It is also a way to implement quality education and train all-round talents. The curriculum objectives of PE teaching are more diversified. The basic goals are based on the foundation of most ordinary students completely replaced by labor, and physical education in colleges and universities is in a halt and retrogression.

and are divided into five areas: the goal of sports participation, motor skills, physical health, mental health and social adaptation, while the development the goal is to differentiate the needs of individual students [5]. Curriculum provides for the first and second year to set up a compulsory course, two school year a total of 144 hours, credit is the student graduate and degree requirements. The structure of the curriculum is more advancing with the times and diversified. It is required to include all kinds of physical exercises and activities outside the classroom, extracurricular, in-school and off-campus activities and sports training into the physical education curriculum system to form courses with internal and external links within and outside the school structure. Students' learning evaluation is required to evaluate students' learning effectiveness and process, and adopts multiple comprehensive evaluation methods to attach importance to students' learning effects in the evaluation process. The new outline of 2002 mainly takes "Health First" as its guiding ideology and breaks through the traditional thought of physical education in colleges and universities; reconstructs the target system of physical education in colleges and universities so that the goal of physical education in colleges and universities can be changed from single to multiple; The structure is richer and advancing with the times; the traditional evaluation system is changed, the content and method of evaluation are more reasonable and scientific, and the goals and functions of evaluation are clarified.

\section{The INFLUENCE OF SPORTS ThOUght EVOLUTION ON PHYSICAL EDUCATION COURSES IN COLLEGES AND UNIVERSITIES}

\section{A. Influence of Technical Education Thoughts on Physical Education Courses in Colleges and Universities}

The idea of technical education is to emphasize the teaching of physical education in basic knowledge, basic skills and basic skills, that is, "three basic" so that students through physical education can have the formation of sports skills and skills have a clearer understanding, Focus on the teaching of motor skills teaching, emphasizing the acquisition of motor skills, biased in sports training. The formation of the thought of technical education in physical education of colleges and universities in our country is mainly influenced by the Soviet Union. The mode, method and content of teaching mainly refer to the former Soviet Union, at the same time, it greatly promoted and developed the teaching of physical education in our country. At the same time, the educational thought makes the purpose of physical education too clear and unilateral, ignores the effect of physical education on the enhancement of students' physique and the healthy development of body and mind. 


\section{B. Influence of Physical Education Thought on Physical Education Courses in Colleges and Universities}

The thought of physical education is a theoretical system that Chinese local scholars put forward and continue to deepen the practice and study. It is proposed that the primary goal of school physical education is to guide the students in physical exercise and physical fitness. After the thought of physical education is established, the structure of the curriculum has been greatly enriched. From physical education with athletics and gymnastics as the main content to multiple sports, the form of classroom teaching is also rich and varied. Classroom teaching emphasis on the promotion of physical health, teachers in each classroom arranged for a certain period of time targeted practice, improve students' physical fitness at the same time to develop the will of students. Physical education thought is a set of comparatively complete theoretical system, which plays an important role in the school PE teaching in our country. However, as the times change, the theory should be continuously improved and adapted to the development of the society.

\section{The Influence of Guiding Ideology of "Health First" to College Physical Education Courses}

The thought of health first has been proposed twice in the history of our country. For the first time in the 1950s, it mainly embodies the essential understanding of the function of school physical education and also the urgent need consciousness to enhance students' physical health. The second proposal in the 1990s is a reflection of the thought of the first sport of diversified and compound health under the current background of quality education for students. The core values are student-centered. Under the guidance of the health first education thought, the main goal of physical education in colleges and universities is to promote the healthy development of students. According to different individuals, it is divided into basic goals and development goals, and the target system is diversified. The curriculum and structure are richer and more stereoscopic. Physical education is combined organically with sports activities both in-class and out-of-class. Physical education is more inclusive. The evaluation of the curriculum is more comprehensive and covers three aspects: curriculum construction, teacher teaching and student learning. At the same time, the evaluation of student learning is more scientific and rational, and the selection and screening functions are diluted, and the development and incentive functions are strengthened. Students learn the results and process, combined with the results of evaluation, attach importance to the evaluation of all relevant aspects [6].

\section{SUMMARY}

The idea of physical education in colleges and universities comes from the theory of educational thought. Under the characteristic times and background, taking the physical education activities of colleges and universities as a platform, the viewpoints and opinions on the essence, function and basic rules of physical education in colleges and universities are formed. After the founding of the People's Republic of China, the thoughts that have a profound impact on the physical education curriculum in higher education in our country mainly include technical education, physical education and health first three, which come from practice and act against teaching practice. These thoughts have a direct impact on the promulgation of our country over the years Four college physical education program. Reasonable college physical education ideals that meet the needs of the times to promote the better development of physical education curriculum is of great significance to the effective reform of physical education curriculum in colleges and universities and to the development of education and the overall national strength of the country. It is hoped that it can provide ideas and ways for the reform of physical education curriculum in colleges and universities through the arrangement of the thoughts affecting the physical education curriculum in colleges and universities in our country, so as to promote the all-round development of personnel training in colleges and universities in our country.

\section{REFERENCES}

[1] Yuan Xiaoping.Changes of School Physical Education Thoughts in Our Country in 30 Years. Journal of Sports, vol.01,pp65-66, 2010.

[2] Zhang Yong and so on,Recent Trends of Physical Education Teaching Content in Colleges and Universities under Leisure Education Background. Journal of Shangdong Institute of Physical Education, vol.25(06), pp 91-93,2009.

[3] Wang Yan and so on, Study on the Development and Implementation Strategies of PE Curriculum Objectives in Colleges and Universities in China. Sports world (Academic Edition), vol. 12,pp 85-86,2012.

[4] Chen Jie. Humanities and Sociology Analysis of the Evolution and Development of School Physical Education in China. Guizhou Normal University, 2006.

[5] Zhang Huihong. Physical Education Curriculum Resources System Theory and Its Empirical Study of the Use of Physical Education in Colleges and Universities. Fujian Normal University, 2006.

[6] ZHAO Jun-rong. An Empirical Study on the Change of Physical Attitude among Students in Normal Colleges and Universities . Journal of Tianjin University of Sport, vol.01, pp 92, 2006. 